Margareta V. Bašaragin, DOI: $10.19090 /$ zop.2016.25.75-97

Svenka L. Savić UDC: 305]:37.016:821-82(075.3)

Univerzitet u Novom Sadu, Stručni rad Centar za rodne studije, ACIMSI

\title{
RODNOOSETLJIVA ANALIZA ČITANKI ZA OSMI RAZRED OSNOVNE ŠKOLE ZA SRPSKI JEZIK, SRPSKI KAO NEMATERNJI I MAĐARSKI JEZIK ${ }^{1}$
}

Apstrakt: Mnogobrojna istraživanja potvrđuju da je tradicionalni patrijarhalni model prisutan u kurikulumima za osnovnu školu. Takođe, potvrđuju postojanje skrivenog ili nevidljivog kurikuluma, kojim se učenicima/ama prenose nepropisani i neplanirani vrednosni stavovi i obrasci ponašanja. Time se dečaci i devojčice i socijalizaciju za drugačije uloge i posredno se utiče na formiranje rodno zasnovanih modela ponašanja. Cilj ovog rada je dekonstrukcija sadržaja i koncepcije čitanki za osmi razred osnovne škole za srpski jezik, srpski kao nematernji i mađarski jezik, čitanki koje su trenutno u upotrebi u Vojvodini, a kroz prizmu rodno oseljive analize kako bi se utvrdilo da li je zaživeo proces integracije rodne ravnopravnosti u udžbenicina u smislu nediskriminatorne obrazovne prakse. Za rodno osetljivu analizu čitanki koriste se istraživački instrumenti sastavljeni za potrebe regionalnog projekta „Rodno senzitivni udžbenici i učionička praksa u regionu Balkana“" (IX 2005-IX 2007). Rezultati potvrđuju da čitanke i dalje reflektuju rodne stereotipe svojim sadržajem i koncepcijom; za prava žena i probleme nejednakosti ne postoji zainteresovanost. Muškarci dominiraju i kao autori književnih tekstova i kao likovi reprezentovani u njima i na slikovnim prilozima uz tekst. Oni su glavni nosioci radnje, sukoba i inicijatori su njihovog razrešavanja. Delovanje ženskih likova usmereno je na nemu podršku muškog društva u kojem je fizička i emotivna briga za dobrobit drugih u porodici i društvu visoko kotirana. Danas ne postoje mehanizmi kojima bi se kontrolisale i otklonile postojeće neusaglašenosti standarda kvaliteta udžbenika koji se odnose na principe jednakih mogućnosti i nediskriminatorne prakse sa sadržajem i koncepcijom udžbenika.

Ključne reči: čitanke za osmi razred osnovne škole, mađarski jezik, rodno osetljiva analiza, srpski jezik.

${ }^{1}$ Margareta Bašaragin, margareta.basaragin@gmail.com, Svenka Savić, svenka@eunet.rs 


\section{Uvod}

Funkcija osnovne škole u socijalizaciji dece i izgradnji rodnih identiteta i uloga predmet je rodnih istraživanja i primena rodnih teorija. Obrazovna politika određuje socijalno legitimna znanja i organizovano putem školskih planova i programa kontroliše formiranje ličnosti deteta (Jarić, 2002: 495). Mnogobrojna istraživanja potvrđuju da je tradicionalni patrijarhalni model prisutan u kurikulumima osnovne škole. Pored sadržaja, on obuhvata i metode, pristup, ciljeve, materijale, načine ocenjivanja i opremu (Petrić, 2006: 13-14). Takođe, potvrđuju postojanje skrivenog ili nevidljivog kurikuluma kojim se učenicima/ama prenose nepropisani i neplanirani vrednosni stavovi i obrasci ponašanja. On znači nejednako prikazivanje učenika/ca u udžbenicima $\mathrm{i}$ različitost u očekivanjima $\mathrm{i}$ zahtevima nastavnog osoblja. Time se dečaci i devojčice socijalizaciju za drugačije uloge i posredno se utiče na formiranje rodno zasnovanih modela ponašanja (Petrić, 2006:18).

Udžbenik je neotuđiv deo nastave bilo da se svrstava u osnovno ili pomoćno nastavno sredstvo, a njegove standarde kvaliteta definišu obrazovni zakonski propisi države. Tako se za Republiku Srbiju standardi definišu kao uslovi koje udžbenici treba da ispune i odnose se na sadržaj, pedagoško-psihološke, didaktičko-metodičke, jezičke, etičko-vaspitne zahteve, te likovnu i tehničku opremljenost. Ovde se posebno ističe pokazatelj za etičko-vaspitni zahtev: „U udžbeniku se afirmišu principi demokratije i ljudska prava, poštuje se rodna ravnopravnost i na prikladan način se koriste imenice oba roda" (Pravilnik o standardima kvaliteta udžbenika i uputstvo o njihovoj upotrebi, 2010), što svedoči o nastojanju uključivanja rodne dimenzije u ovu oblast. Zakon o udžbenicima (2015) uvodi važne novine u kontekst integracije rodne ravnopravnosti i razvoja interkulturalnosti u nastavnoj praksi. Zakon predviđa da su izdavačke kuće obavezne da prevode i štampaju udžbeničke komplete i na jezicima naconalnih manjina (Član 3). Članom 11 omogućava se sprovođenje principa jednakih mogućnosti i zabrana diskriminacije sadržajem i oblikom udžbenika.

Udžbenici imaju tri funkcije: podučavajuću, didaktičku i vanškolsku (Paseka, 2004: 54). One su ogledalo normi i vrednosti jednog društva i mogu biti političko sredstvo time što selektuju sadržaje, ispuštaju ih ili iskrivljeno prikazuju. Njihove sadržaje interpretiraju nastavnici/e svojim vrednosnim angažmanom. 
Dijana Plut (2004) istražuje bazični socijalizacijski model osnovnoškolskih udžbenika, koji se ovde detaljnije prikazuje. Navodi njegova tri osnovna strukturna elementa do kojih je došla u svojim istraživanjima: borba za suverenitet zajednice, borba za socijalnu pravdu i borba za pravičnu raspodelu moći u društvu. Osnovne koordinate ovog modela su odnosi ja - ti, mi - vi i novo - staro, a socijalizacijski narativ glasi: Ja sa drugima, naše protiv tuđeg, novo koje je nastalo iz dobre prošlosti. Zanimljivo je njeno stanovište da pozitivan rodni model treba prilagoditi ovom dominantnom, i to odgovorima na sledeća pitanja: 1 . Kako želimo da izgleda slika žena o sebi? Šta one treba da žele od sebe (žensko $» j a \ll)$ ? 2. Kakav je odnos žena prema drugim ženama, muškarcima i svojim bližnjima uopšte (žensko »ti«)? 3. Kako se žene kao grupa identifikuju (žensko »mi«)? 4. Ko su za žene »oni« i kakav je odnos prema njima? 5. Kako konstruišemo žensku prošlost (žensko »staro«)? 6. Kako konstruišemo žensku budućnost (žensko »novo«)? 7. Kakav je odnos »ja - ti«? 8. Kakav je odnos »mi - oni«? 9. Kakav je odnos »novo - staro« u pozitivnom rodnom modelu? (Plut, 2004: 48).

Eva Toldi se zalaže za udžbenik integrisanog tipa pozivajući se na rad Lenke Erdelj. Ovakav udžbenik objedinjuje materiju više predmeta tako da uobličava kulturni identitet, interkulturalnost, komunikativnu toleranciju time što raspolažemo saznanjima i razumevanjima vlastite i tuđe kulture podjednako (Toldi, 2005: 33).

Tokom poslednje decenije nastao je čitav niz radova regionalnog i domaćeg karaktera kojima se prezentuju istraživanja o rodno osetljivim analizama udžbenika za osnovnu školu (Đorić, Žunić, ObradovićTošić, 2010; Grbić 2007; Kovačević, Kosić, Jurlina, 2004; Kožul, 2007; Marić, 2011; Milinković 2009; Nikolić 2007; Savić 2009; StjepanovićZaharijevski, Gavrilović, Petrušić 2010, i dr). Detektuju se rodni stereotipi kao sastavni deo tradicionalnog patrijarhlanog modela socijalizacije, tj. očekivani društveni modeli muškosti i ženskosti na osnovu biološkog pola koji ni u kojem slučaju ne nudi uspostavljanje principa jednakih mogućnosti. Takođe se iskazuje zalaganje za uvođenje rodno osetljivog jezika (u daljem teksu: ROJ) u udžbenik, sa pretpostavkom da se osvajanjem ROJ-a može uticati na svest onih koji se tim jezikom koriste u pravcu ostvarivanja rodne ravnopravnosti (Savić, Čanak, Mitro, Štasni, 2009: 7). Međutim, ta suma znanja nije postala dostupna široj javnosti, niti je internalizovana u postojeće planove i programe; zato ni rezultati i efekti istraživanja nisu veliki. 
Teorijsko-metodološki okvir rada temelji se na sociokognitivnom pristupu u kritičkoj analizi diskursa (u daljem tekstu: KAD) Tojna van Dijka (Teun van Dijk, 1993, 2009) i diskurs analizi (Savić, 1993). KAD istražuje odnose diskursa, moći, dominacije, socijalne nejednakosti i poziciju istraživača/ice u takvoj socijalnoj relaciji. Fokus se nalazi na ulozi diskursa u re/produkciji dominacije, tj. ispoljavanju socijalne moći određene elite, institucije ili grupe koja rezultira socijalnom nejednakošću (van Dijk, 1993: 249-250).

Socijalna moć je višeslojna i višedimenzionalna. U obrazovnom institucionalnom diskursu je hijerarhijski organizovana, sa jasnim strukturama i mehanizmima kontrole i samozaštite. Na vrhu hijerarhije moći nalazi se zakonodavac (Narodna skupština, Ministarstvo prosvete i tehnološkog razvoja Republike Srbije) koji donosi zakonske regulative i propise, potom i ministar prosvete kao odgovorno lice za njihovo sprovođenje, donošenje podzakonskih akata i kao osoba koja po zakonu ima manje ili više ograničeno pravo i moć odlučivanja. Nacionalni prosvetni savet - kao pretpostavljena obrazovna i akademska elita - donosi programe i planove nastavnih predmeta, standarde kvaliteta udžbenika, postignuća učenika/ca i kompetencija nastavnog osoblja. Autori/ke užbenika, još više recenzenti/kinje, imaju moć oblikovanja sadržaja udžbenika a nastavno osoblje moć njihove konkretne realizacije. Na kraju ove hijerarhijske strukture stoje učenici/e kao ciljana grupa u kontekstu usvajanja ,poželjnih“ znanja i ideologija.

\section{Cilj i metod}

Cilj ovog rada je dekonstrukcija sadržaja i koncepcije čitanki za osmi razred osnovne škole za srpski jezik, srpski kao nematernji i mađarski jezik, tj. čitanki koje su trenutno u upotrebi u Vojvodini, i to kroz prizmu rodno oseljive analize kako bi se utvrdilo da li je zaživeo proces integracije rodne ravnopravnosti u udžbenicima u smislu nediskriminatorne obrazovne prakse.

Korpus se sastoji od čitanke za osmi razred osnovne škole za nastavu srpskog jezika (u daljem tekstu: SJ), čitanke za srpski kao nematernji (u daljem tekstu: SKN) i čitanke za nastavu mađarskog jezika (u daljem tekstu: MJ). Čitanka za SJ nosi naslov: Umetnost reči. Čitanka za osmi razred osnovne škole, treće izdanje, godina izdanja 2012; autorka je mr Nataša Stanković-Šošo, recezenti prof. dr Mihajlo Pantić (Filološki 
fakultet, Beogradski univerzitet), doc. dr Branka Jakšić-Provči (Filozofski fakultet, Novosadski univerzitet) i Dragana Nikolin-Kolarić, profesorka srpskog jezika (OŠ „Rade Končar”, Zemun); izdavač - Novi Logos, Beograd. Čitanka sadrži 254 stranice i 48 tematskih jedinica.

Čitanka za SKN nosi naslov: Nedokučive tajne uma i srca: srpski kao nematernji jezik, prvo izdanje, 2010; autorke su Gordana Štasni i Nataša Dobrić, recezenti prof. dr Pavle Ivić (red. prof. metodike nastave srpskog jezika i književnosti u penziji), prof. dr Ljiljana Petrovački (red. prof. metodike srpskog jezika na Odseku za srpski jezik i lingvistiku Filozofskog fakulteta Univerziteta u Novom Sadu), Ljiljana Cerovac (nastavnica srpskog jezika kao nematernjeg i srpskog jezika i književnosti u OŠ „Narodni heroji”, Čantavir) i Karolina Gašparovski (nastavnica srpskog jezika kao nematernjeg i srpskog jezika i književnosti u OŠ „,15. oktobar ", Pivnice); izdavač - Zavod za udžbenike iz Beograda. Čitanka sadrži 211 stranica i 41 tematsku jedinicu.

Naslov čitanke za MJ je: Olvasókönyv az általános iskolák 8. osztálya számára, prvo uzdanje, 2010; autorka je dr ${ }^{21}$ Eva Toldi (Toldi Éva), recenzent i recenzentkinje su dr Laslo Gerold (Gerold Laszló) (univerzitetski profesor u Novom Sadu), Eržebet Rokvić Horongozo (Rokvić Harangozó Erzsébet) (OŠ „Petőfi Sándor“, Novi Sad) i Lenke Erdelj (Erdély Lenke) (Pedagoški zavod Vojvodine, Novi Sad); izdavač Zavod za udžbenike iz Beograda. Čitanka sadrži 172 stranice i 64 tematske jedinice.

Za rodno osetljivu analizu čitanki upotrebljena je istraživačka matrica sastavljena za potrebe regionalnog projekta „Rodno-senzitivni udžbenici i učionička praksa u regionu Balkana“ („Gender sensitive textbooks and classroom practice in the Balkan region") (IX 2005-IX 2007). ${ }^{3}$ Cilj projekta je ,problematizirati pitanje rodne (ne)osjetljivosti čitanki književnosti i nastavne prakse u obaveznom obrazovanju na osnovi rezultata empirijskog istraživanja“" (Baranović i dr., 2008: 9). Nastavlja se na istraživanja Branislave Baranović o prikazu žene u udžbenicima

${ }^{2}$ Autorka ima zvanje ,doktor nauka”, ali to nije naznačeno u čitanci.

${ }^{3}$ Projekat je podržan od strane Fonda otvoreno društvo Budimpešta i na njemu je sarađivalo sedam partnerskih institucija/organizacija: CG: NVO „Ženska akcija“, Nikšić; RH: Institut za društvena istraživanja, Centar za obrazovanje i razvoj istraživanja, Zagreb; RS (BiH): Gender centar - Centar za jednakost i ravnopravnost polova Vlade Republike Srpske, Banja Luka; Federacija BiH: Centar „Žena i društvo“, Sarajevo; RS: HORA Grupa za emancipaciju žena, Valjevo; Vojvodina: CRS, UNS, Novi Sad; Kosovo: Centar za edukaciju, Fakultet za psihologiju, Priština. 
hrvatskog jezika i književnosti u osnovnim i srednjim školama, koje je sprovedeno krajem devedesetih godina prošlog veka (Baranović, 2000).

Istraživački instrumenti sastoje se od „Istraživačke matrice za udžbenike” i „Knjige koda za popunjavanje istraživačke matrice”. Knjiga koda sastoji se od 99 pitanja grupisanih u sledeće celine:
A. Osnovni podaci;
B. Podaci o udžbeniku;
C. Podaci o tekstu;
D. Podaci o opremi, književnoj formi i sadržaju teksta: a) oprema teksta, b) književne forme teksta, c) teme teksta;

E. Pitanja o muškim i ženskim likovima: a) zastupljenost, dob i rezidencijalni status ženskih i muških likova, b) sukobi, c) društveni položaj i prava žena, nasilje nad ženama, d) porodica, porodične uloge i odnosi muških i ženskih likova, e) profesionalne uloge ženskih i muških likova, f) osobine ženskih i muških likova, g) vrednosti i interesovanja ženskih i muških likova;

F. Dečije igre.

Pored navedenih celina, Knjiga koda sadrži i uputstva za popunjavanje istraživačke matrice. Pitanja su zatvorenog tipa i nude unapred utvrđene varijable i parametre; na primer, za pozitivne osobine ženskih likova date su 44 takve osobine označene brojem. U istraživačkoj matrici u prvoj kućici beleži se prisustvo određene osobine (dati broj) a u drugoj učestalost njenog pojavljivanja u određenom tekstu. Tako se kasnijom obradom dobijaju postotak i frekvencija pojavljivanja te osobine. Pitanja vezana za „Dečije igre“ nisu obuhvaćena analizom pošto u čitankama za osmi razred nisu ni sadržajno ni metodološki prisutna.

Za obradu podataka dobijenih analizom uz pomoć opisane istraživačke matrice korišćen je kompjuterski program SPSS. To je program za statističku obradu podataka kojim su mereni frekvencija i postotak određenih varijabli (prema „Knjizi koda“) putem deskriptivne statistike.

Osnovna jedinica analize u ovom radu je tematska jedinica (lekcija), kojom se označava „pisani deo udžbenika koji čini sadržajnu celinu s jasno označenim početkom i krajem, počinje naslovom, a završava se metodičkom obradom dela, odnosno pitanjima i zadacima za učenike/ ce“" (Stefanović, Glamočak, 2008: 11). 


\section{Rezultati istraživanja i diskusija}

Sledi prezentuja nekih od najtipičnijih rezultata iz analize; grupisani su u tri celine:

1. podaci o opremi, formi i sadržaju teksta;

2. sukobi, društveni položaj i prava žena, nasilje nad ženama i muškarcima, $\mathrm{i}$

3. profesionalne uloge, osobine, vrednosti i interesovanja muških i ženskih likova.

\section{Podaci o opremi, formi i sadržaju teksta}

Čitanka za srpski jezik (SJ) sadrži tekstove - u odnosu na mnogo veći broj autora - svega tri autorke: Isidore Sekulić, Desanke Maksimović i Jasminke Petrović; čitanka za srpski kao nematernji jezik (SKN) četiri: Milice Janković, Desanke Maksimović, Gordane Maletić i Jasminke Petrović a čitanka za mađarski jezik (MJ) pet autorki: Ane Frank, Agneš Nemeš Nađ (Nemes Nagy Ágnes), Vide Ognjenović, Estere Tot (Tóth Eszter) i Kristine Tot (Tóth Krisztina). Grafikoni 1, 2 i 3 pokazuju pol autora/ki tekstova (parametar ,nepoznato” odnosi se na tekstove iz narodne književnosti i naučno-popularne tekstove, kod kojih autorstvo nije navedeno):

\section{Grafikon 1}

Pol autora/ki tekstova u čitanci za SJ

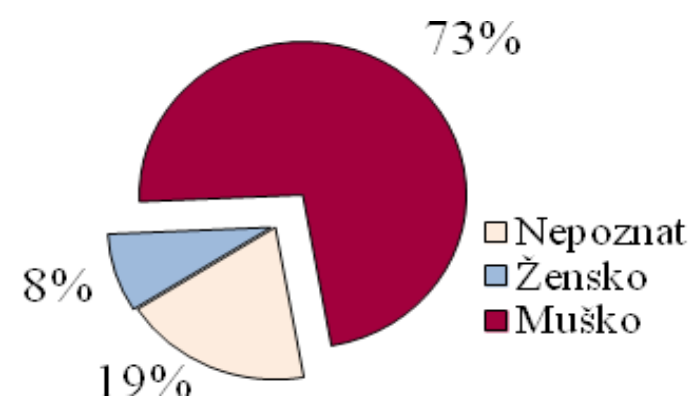


Grafikon 2

Pol autora/ki tekstova u čitanci za SKN

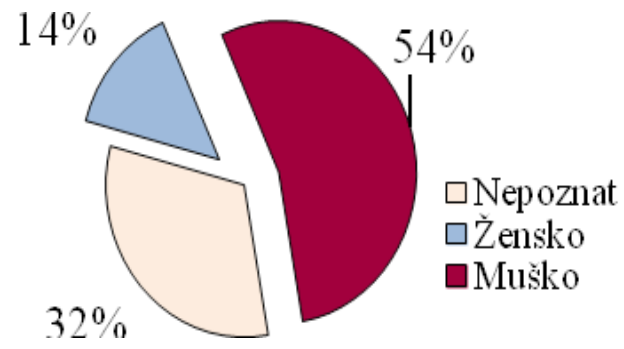

Grafikon 3

Pol autora/ki tekstova u čitanci za MJ

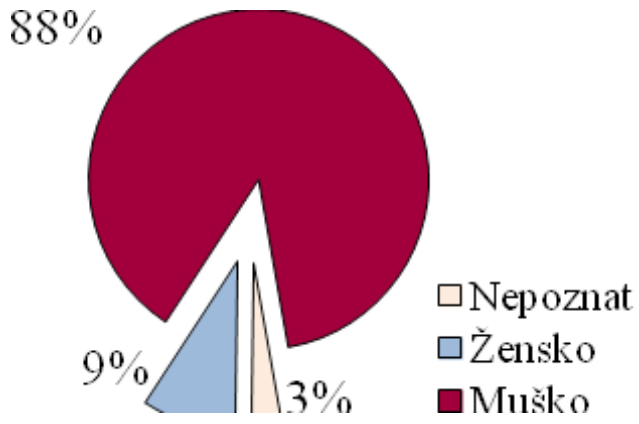

Ovakvi podaci potvrđuju da je izbor tekstova „muški” i da ni sam nastavni program ni čitanke ne uključuju književno-umetničke doprinose žena. Naročito je nepovoljna slika u čitankama za SJ i MJ, gde svega 8\% odnosno 9\% tekstova potpisuju žene.

Tekstovi su u sve tri čitanke uglavnom praćeni slikovnim prilozima, na kojima se prikazuju „samo” ili „pretežno” muški likovi (Grafikoni 4, 5 i 6). U čitanci za SKN brojniji su slikovni prilozi na kojima su podjednako prikazani muški i ženski likovi. Iako je ukupni procenat muških likova niži na slikovnim prilozima u čitanci za MJ u odnosu na njihov sadržaj, niži je i procenat podjednakog prikazivanja muških i ženskih likova. Ovi rezultati potvrđuju ranije analize čitanki za SJ (Stefanović, Glamoček, 2008) i za SKN (Grbić, 2007). Istovremeno, beleži se porast zajedničkog predstavljanja muških i ženskih likova. Ovo bi predstavljalo iskorak u nastojanju približavanja muškog i ženskog „,sveta“ da se, nažalost, i dalje 
ne prikazuju sasvim odvojeno, i to sa muškim kao preovlađujućim.
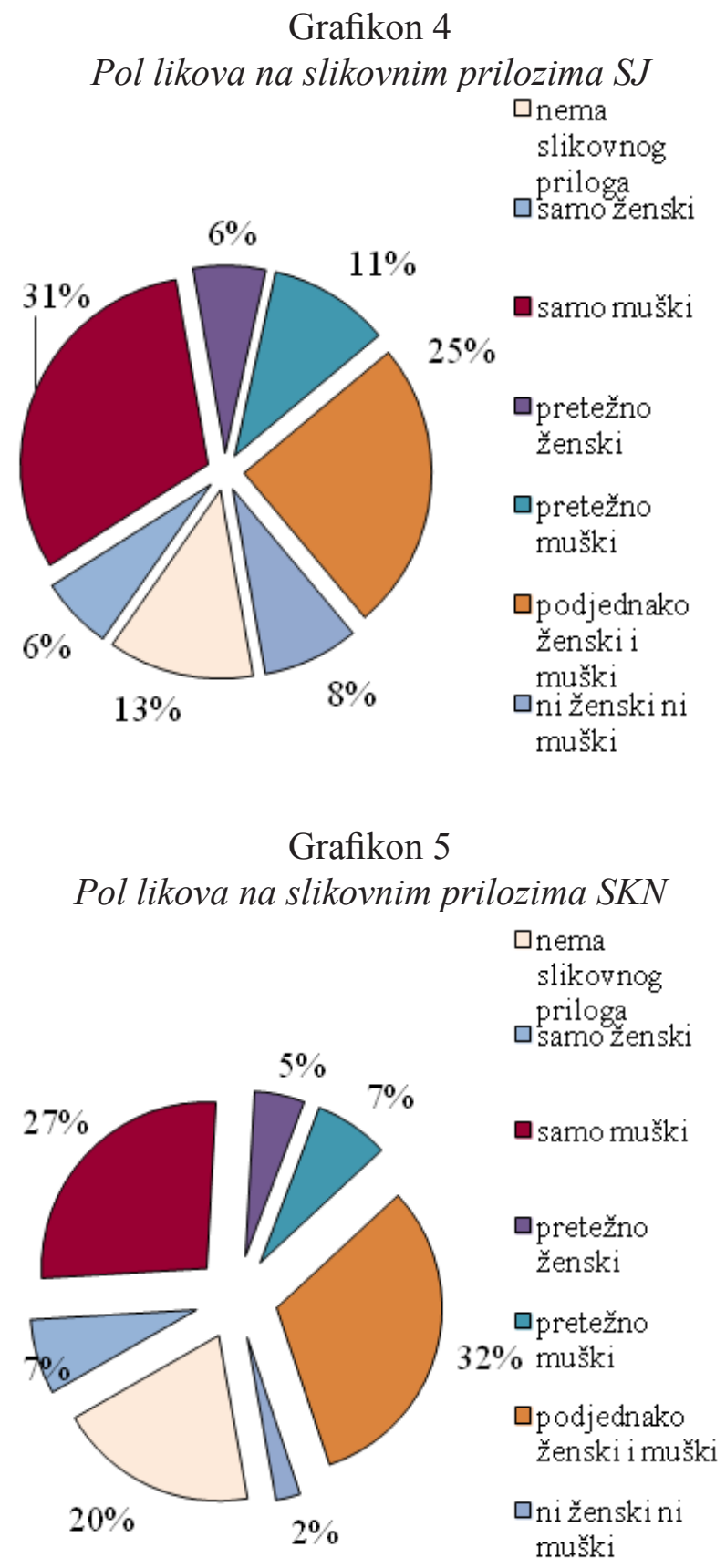


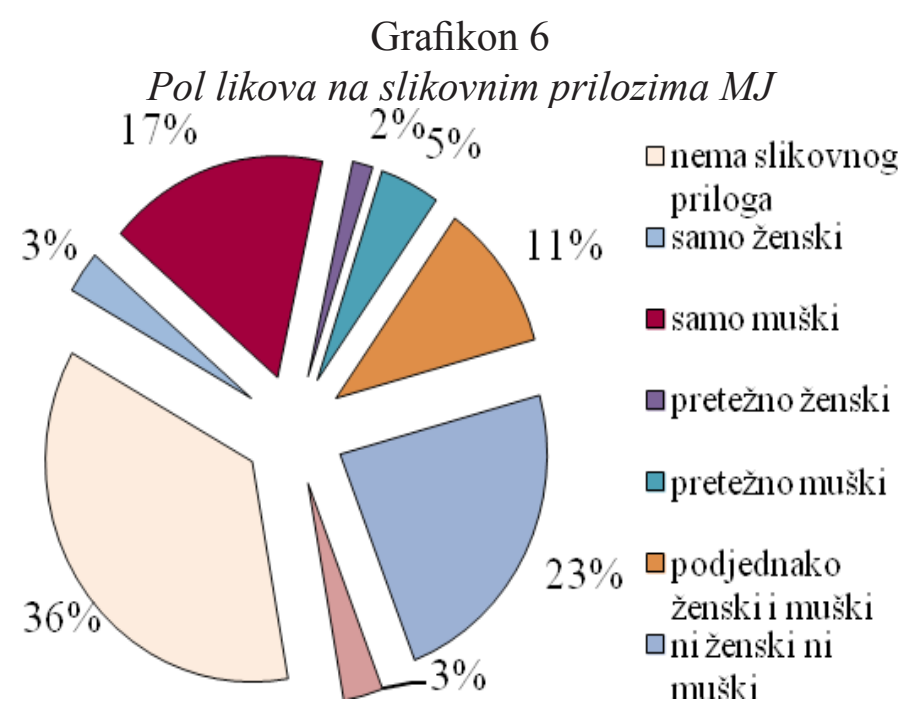

Tekstovi čitanki za SJ i SKN su uvek nacionalno obeleženi, što dokazuje da su pitanja nacionalnog identiteta izuzetno visoko kotirana. Slično je i sa čitankom za MJ, gde dominiraju mađarski autori (i nad autorkama): od ukupno njih 38 na mađarskom jeziku, svega su dve žene, šest autora je poreklom sa vojvođanskog prostora a jedan je rodom iz Slovačke.

Najdominatnija tema u čitanci za SJ je ,intimni život” (Grafikon 7), u čitanci za MJ ,čovek i svet ili egzistencijalne teme" (Grafikon 8) a u čitanci za SKN „ostale teme” (Grafikon 9).

\section{Grafikon 7}

Dominantne teme tekstova SJ
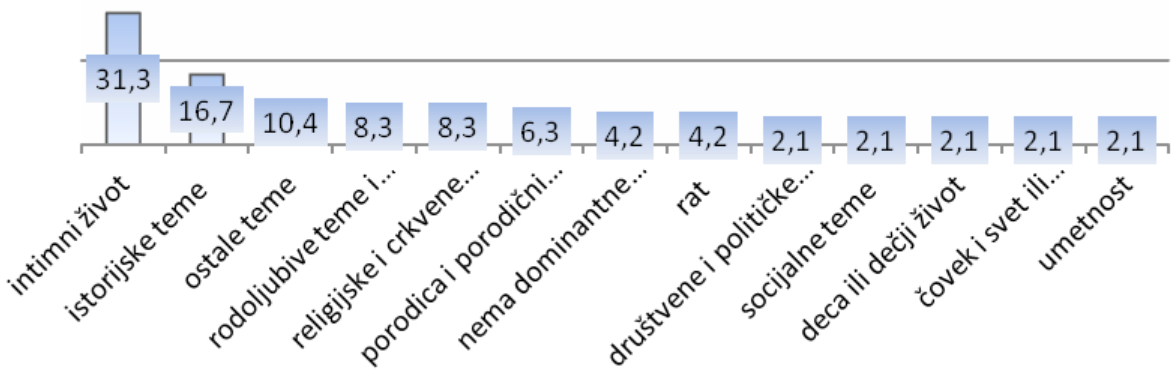


\section{Grafikon 8}

Dominantne teme tekstova SKN

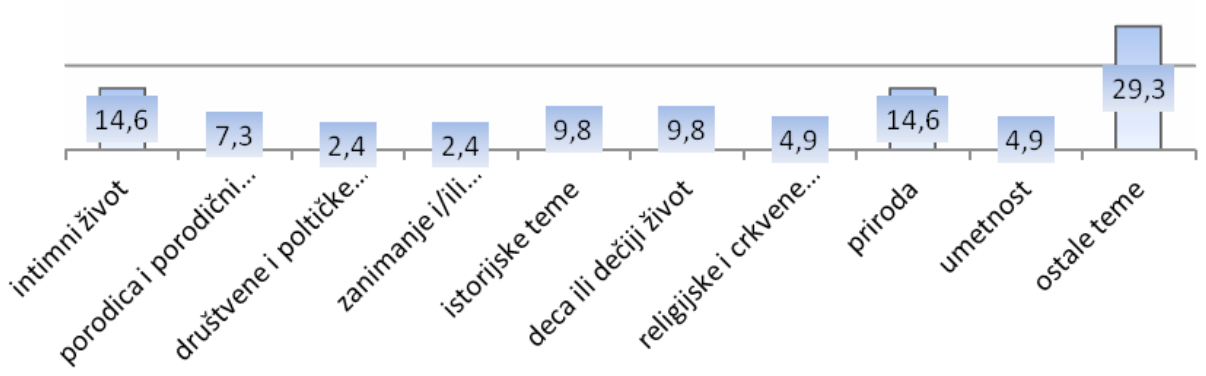

Grafikon 9

Dominantne teme tekstova MJ
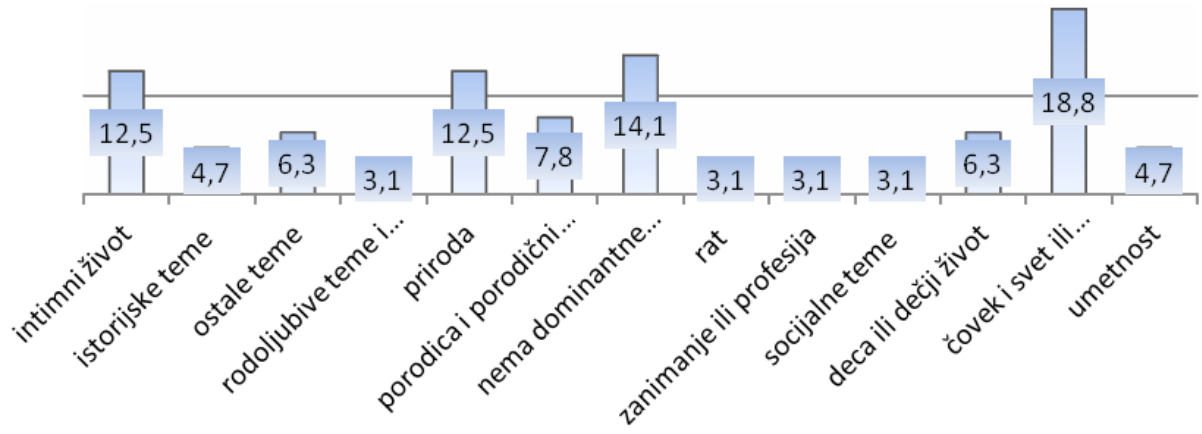

Istorijska, rodoljubiva i religiozna tematika zajedno čine stvarnu dominaciju tradicionalizma i patrijarhata u tekstovima čitanke za SJ. Teme „prirode” i ,zanimanja i/ili profesije” javljaju se u čitankama za SKN i MJ, a u čitanci za SJ ne, iako su to aktuelna interesovanja mladih ovog uzrasta.

Interpretacijom sadržaja teksta dopunjeno je čak 97,9\% tekstova u čitanci za SJ, 57,8 \% u čitanci za MJ a u čitanci za SKN - svi tekstovi. $\mathrm{U}$ interpretaciji tekstova u čitanci za SJ pretežno se govori o muškim likovima, a u čitanci za SKN najvećim procentom ni o muškim ni o ženskim. U čitanci za MJ interpretacija teksta se u najvećem procentu ne odnosi ni na muške ni na ženske likove ili se govori podjednako o muškim i ženskim. Ovi podaci za SJ i SKN u skladu su sa polom glavnog lika (up. pol glavnog lika), za čitanku za MJ u tesnoj su vezi sa preovladavajućom tematikom (egzistencijalne teme, čovek). Zaključak je da se na časovima SJ i SKN najviše govori o muškarcima kada se obrađuju literarni tekstovi. 
Sukobi, društveni položaj i prava žena, nasilje nad ženama i muškarcima

Pol glavnog lika je u tekstovima iz čitanke za SJ u 52\% slučaja muški (Grafikon 10), u čitanci za SKN 44\% (Grafikon 11), a rapidno opada u čitanci za MJ i iznosi 26,6\% (Grafikon 12); 57,8\% tekstova čitanke za MJ i 27\% tekstova čitanke za SKN ne spominju kao glavne ni muške ni ženske likove, što predstavlja napredak u smislu vrednosno neutralnog angažmana. Međutim, ženski likovi kao glavni prisutni su u tekstovima čitanke za MJ u svega 3,1\%, što i dalje podupire predstavu žena kao pasivnih objekata.

Grafikon 10
Pol glavnog lika SJ

muški
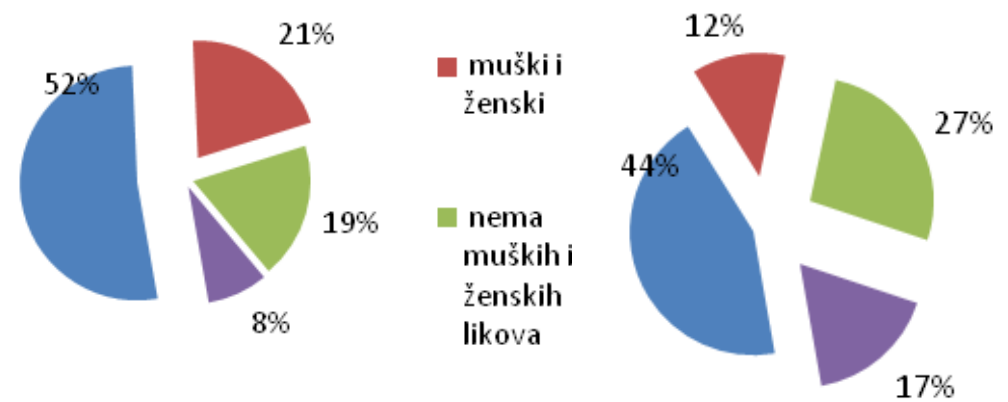

muški i

ženski

nema muških i ženskih likova ženski

Grafikon 11

Pol glavnog lika MJ

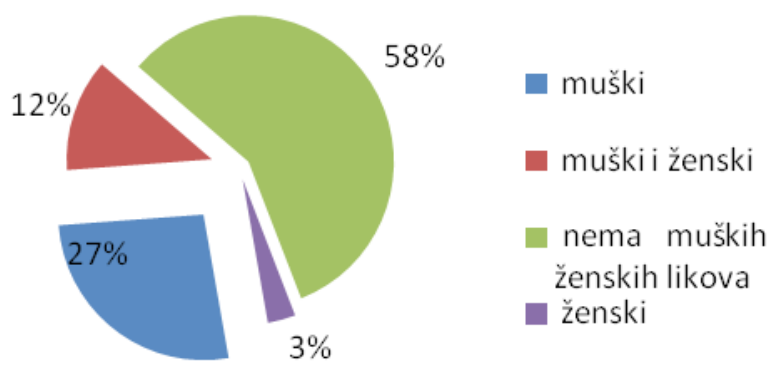


Sukobi su veoma retko zastupljeni u sve tri čitanke. Kada se i opisuju, onda ih likovi muškog pola izazivaju i iniciraju njihovo rešenje. Upotrebom psihičkog i fizičkog nasilja akter u čitanci za SJ razrešava sukob u 18,8 \% slučajeva, u SKN 4,9\% a u MJ 9,4\%. Nenasilna sredstva prisutna su 4,9\% u čitanci za SJ, 22\% u SKN i 25\% u MJ. Nažalost, u razrešavanju sukoba nasilje dominira u čitanci za $\mathrm{SJ}$, dok u čitankama za SKN i MJ primat imaju nenasilna sredstva.

O društvenoj nejednakosti žena i muškaraca govori se u šest tekstova u čitanci za SJ. Pri tome se u neravnopravnom položaju nalaze samo ženski likovi, i to u odnosu na društvo, porodicu i privatan odnos. U čitanci za SKN u samo jednom tekstu („Čovek i sport”) razmatra se neravnopravan položaj ženskog lika u društvu. Osam tekstova u čitanci za MJ tematizuje društvenu nejednakost žena i muškaraca: u privatnom odnosu, porodici, na radnom mestu i društvu. U neravnopravnom položaju nalaze se muški i ženski likovi zajedno, osim u jednom slučaju, na radnom mestu, i tosamo muški lik.

U čitanci za SKN u dva se teksta govori o pravima žena kulturnim („Izbiračica” Koste Trifkovića) i socijalnim („Čovek i sport”). U čitanci za SJ tekst Borislava Mihajlovića Mihiza „Banović Strahinja” i narodna balada „Hasanaginica” problematizuju kulturna prava žena. Po jedan tekst u čitanci za MJ tematizuje socijalna („Bede Anna tartozása Kalmana Miksaća” /Mikszáth Kálmán/) i kulturna („Anne Frank naplója /Részletek/)" prava. Zaključak: sasvim nedovoljno pažnje posvećuje se ovom problemu.

Psihičko i fizičko nasilje u sve tri čitanke muški likovi najčešće trpe, ali ga i sprovode. Broj tekstova koji problematizuju nasilje - pogotovo nad ženskim likovima - nedostatan je, što potvrđuje da nasilje nije uočeno kao aktuelna tema (mada su pisci obrazovne politike Republike Srbije označili projekat „Škola bez nasilja” kao izuzetno prioritetan).

\section{Profesionalne uloge, osobine, vrednosti i interesovanja muških i ženskih likova}

Profesionalne uloge ženskih likova spominju se u $17,1 \%$ tekstova u čitanci za SKN, 20,8\% za SJ i 15,6\% za MJ. Ne postoji niti jedno zanimanje koje dominira mada su zanimanja jasno stereotipno ženska (Tabela 1). 
Tabela 1 - Profesionalne uloge ženskih likova

\begin{tabular}{|c|c|c|c|c|c|c|c|c|}
\hline Čitanka za SJ & & & $\begin{array}{l}\text { Čitanka za } \\
\text { SKN }\end{array}$ & & & Čitanka za MJ & & \\
\hline $\begin{array}{l}\text { Profesionalna } \\
\text { uloga }\end{array}$ & f & $\%$ & $\begin{array}{l}\text { Profesionalna } \\
\text { uloga }\end{array}$ & f & $\%$ & $\begin{array}{l}\text { Profesionalna } \\
\text { uloga }\end{array}$ & $\mathbf{F}$ & $\%$ \\
\hline \multirow[t]{3}{*}{ domaćica } & 2 & 4,2 & umetnica & 2 & 4,9 & učenica & 3 & 4,7 \\
\hline & & & & & & $\begin{array}{l}\text { kuvarica, } \\
\text { pekarka }\end{array}$ & 2 & 3.1 \\
\hline & & & & & & seljanka & 2 & 3,1 \\
\hline
\end{tabular}

Profesionalne uloge muških likova spominju se u 66,7\% tekstova čitanke za SJ, 61\% za SKN i 34,4\% za MJ (dakle, skoro duplo manje) (Tabela 2). U čitanci za SJ su stereotipi koji odslikavaju iskrivljeno stanovište da je javna sfera oblast delovanja isključivo muškaraca. U čitankama za SKN i MJ dominantna zanimanja muških likova upućuju na zaključak da je domen učenosti i umetnosti - muški.

Tabela 2 - Profesionalne uloge muških likova

\begin{tabular}{|c|c|c|c|c|c|c|c|c|}
\hline Čitanka za SJ & & & $\begin{array}{l}\text { Čitanka za } \\
\text { SKN }\end{array}$ & & & Čitanka za MJ & & \\
\hline $\begin{array}{l}\text { Profesionalna } \\
\text { uloga }\end{array}$ & $\mathbf{F}$ & $\%$ & $\begin{array}{l}\text { Profesionalna } \\
\text { uloga }\end{array}$ & $\mathbf{F}$ & $\%$ & $\begin{array}{l}\text { Profesionalna } \\
\text { uloga }\end{array}$ & f & $\%$ \\
\hline državnik, princ & 15 & 31,3 & nastavnik & 7 & 17,1 & učenik & 6 & 9,4 \\
\hline $\begin{array}{l}\text { vojno lice, } \\
\text { oficir }\end{array}$ & 13 & 27,1 & pisac & 6 & 14,6 & nastavnik & 5 & 7,8 \\
\hline $\begin{array}{l}\text { verski vođa, } \\
\text { sveštenik }\end{array}$ & 10 & 20,8 & ist. ličnost & 6 & 14,6 & $\begin{array}{l}\text { vojno lice, } \\
\text { oficir }\end{array}$ & 4 & 6,3 \\
\hline ist. ličnost & 9 & 18,8 & državnik, princ & 5 & 12,2 & pisac & 4 & 6,3 \\
\hline sluga & 6 & 12,4 & službenik & 4 & 9,8 & & & \\
\hline seljak & 5 & 10,4 & seljak & 4 & 9,8 & & & \\
\hline umetnik & 5 & 10,4 & & & & & & \\
\hline
\end{tabular}


Pozitivne psiho-socijalne osobine ženskih likova opisuju se u $35,4 \%$ tekstova u čitanci za SJ, 34,1\%, za SKN i svega 15,6\% za MJ. Ženski likovi najčešće su „osećajni i saosećajni” u čitankama za SJ i SKN (Tabela 3). Na drugom mestu u SKN je, nestereotipno, ,preduzimljivost” kao pozitivno obeležje ženskih likova. U čitanci za MJ ističe se samo „ljubaznost”, koju možemo shvatiti kao stereotipno očekivanu, dok ostale osobine imaju veoma nisku frekvenciju.

Tabela 3 - Pozitivne psiho-socijane osobine ženskih likova

\begin{tabular}{|c|c|c|c|c|c|c|c|c|}
\hline Čitanka za SJ & & & $\begin{array}{l}\text { Čitanka za } \\
\text { SKN }\end{array}$ & & & $\begin{array}{l}\text { Čitanka za } \\
\text { MJ }\end{array}$ & & \\
\hline $\begin{array}{l}\text { Psiho-socijana } \\
\text { osobina }\end{array}$ & $\mathbf{F}$ & $\%$ & $\begin{array}{l}\text { Psiho-socijalna } \\
\text { osobina }\end{array}$ & $\mathbf{F}$ & $\%$ & $\begin{array}{l}\text { Psihoso-cijalna } \\
\text { osobina }\end{array}$ & $\mathbf{F}$ & $\%$ \\
\hline $\begin{array}{l}\text { osećajna i } \\
\text { saosećajna }\end{array}$ & 11 & 22,9 & $\begin{array}{l}\text { osećajna i } \\
\text { saosećajna }\end{array}$ & 5 & 12,2 & ljubazna & 4 & 6,3 \\
\hline verna & 4 & 8,3 & $\begin{array}{l}\text { aktivna, } \\
\text { preduzimljiva }\end{array}$ & 4 & 9,8 & odlučna & 3 & 4,7 \\
\hline draga, mila & 3 & 6,3 & Poslušna & 3 & 7,3 & & & \\
\hline poslušna & 3 & 6,3 & & & & & & \\
\hline $\begin{array}{l}\text { (samo) } \\
\text { požrtvovana }\end{array}$ & 3 & 6,3 & & & & & & \\
\hline Stidljiva & 3 & 6,3 & & & & & & \\
\hline
\end{tabular}

$\mathrm{f}=$ frekvencija, $\%=$ postotak

Pozitivne psiho-socijalne osobine muških likova date su u 62,5\% tekstova u čitanci za SJ, 53,7\% za SKN i samo 29,7\% za MJ. Zanimljivo je da su muški likovi najčešće „osećajni i saosećajni” u čitankama za SJ i SKN, kao što su to i ženski likovi (Tabela 4). Ovaj podatak potkrepljuje ideju da postoji nastojanje da se muški likovi prikazuju putem emocionalne obojenosti, ali je uočljivo da „Knjiga koda” nije dovoljno precizna u tome da prikaže kontekst ove pojačane senzibilnosti. Ostale osobine su setreotipno očekivane vrline koje krase muške likove. 
Tabela 4 - Pozitivne psiho-socijalne osobine muških likova

\begin{tabular}{|c|c|c|c|c|c|c|c|c|}
\hline Čitanka za SJ & & & $\begin{array}{l}\text { Čitanka za } \\
\text { SKN }\end{array}$ & & & Čitanka za MJ & & \\
\hline $\begin{array}{l}\text { Psiho-socijana } \\
\text { osobina }\end{array}$ & $\mathbf{F}$ & $\%$ & $\begin{array}{l}\text { Psiho-socijalna } \\
\text { osobina }\end{array}$ & $\mathbf{F}$ & $\%$ & $\begin{array}{l}\text { Psiho-socijalna } \\
\text { osobina }\end{array}$ & f & $\%$ \\
\hline $\begin{array}{l}\text { osećajan i } \\
\text { saosećajan }\end{array}$ & 12 & 25 & $\begin{array}{l}\text { aktivan, } \\
\text { preduzimljiv }\end{array}$ & 12 & 29,3 & iskren & 9 & 14,1 \\
\hline $\begin{array}{l}\text { inteligentan, } \\
\text { pametan }\end{array}$ & 10 & 20,8 & $\begin{array}{l}\text { osećajan i } \\
\text { saosećajan }\end{array}$ & 11 & 26,8 & marljiv & 8 & 12,5 \\
\hline $\begin{array}{l}\text { aktivan, } \\
\text { preduzimljiv }\end{array}$ & 8 & 16,7 & $\begin{array}{l}\text { inteligentan, } \\
\text { pametan }\end{array}$ & 6 & 14,6 & odlučan & 7 & 10,9 \\
\hline hrabar & 8 & 16,7 & marljiv & 6 & 14,6 & ljubazan & 6 & 9,4 \\
\hline $\begin{array}{l}\text { (samo) } \\
\text { požrtvovan }\end{array}$ & 6 & 12,5 & & & & hrabar & 6 & 9,4 \\
\hline pobožan & 5 & 10,4 & & & & razborit & 6 & 9,4 \\
\hline marljiv & 4 & 8,3 & & & & spretan & 4 & 6,3 \\
\hline
\end{tabular}

Negativne psiho-socijalne osobine ženskih likova prisutne su u $18,8 \%$ tekstova u čitanci za SJ, $14,6 \%$ za SKN, za trećinu manje nego muških likova, i 14,15\% za MJ, što je skoro za polovinu manje u odnosu na karakterizaciju muških likova. Njihova frekvencija je niska u sve tri čitanke. U čitanci za MJ su u - odnosu na ostale dve - ove osobine najfrekventnije, i to posebno osobine ,plašljiva”, ,svadljiva” i ,zlonamerna (zla)”, a u čitanci za SJ se ističe samo „nepopustljiva”.

Negativnih psiho-socijalnih osobina muških likova u čitanci za SJ ima u 50\% tekstova, za SKN je taj postotak 29,3\% a za MJ 25\%. Nažalost, muški likovi se u sve tri čitanke najčešće karakterišu kao „nasilni”. Takva karakterizacija muških likova ne doprinosi razbijanju predrasuda o nasilništvu (Tabela 5). 
Tabela 5 - Negativne psiho-socijalne osobine muških likova

\begin{tabular}{|c|c|c|c|c|c|c|c|c|}
\hline Čitanka za SJ & & & $\begin{array}{l}\text { Čitanka za } \\
\text { SKN }\end{array}$ & & & Čitanka za MJ & & \\
\hline $\begin{array}{l}\text { Psiho-socijana } \\
\text { osobina }\end{array}$ & f & $\%$ & $\begin{array}{l}\text { Psiho-socijalna } \\
\text { osobina }\end{array}$ & $\mathbf{f}$ & $\%$ & $\begin{array}{l}\text { Psiho-socijalna } \\
\text { osobina }\end{array}$ & $\mathbf{F}$ & $\%$ \\
\hline nasilan & 11 & 22,9 & nasilan & 3 & 7,3 & hvalisav & 7 & 10,9 \\
\hline plašljiv & 7 & 14,6 & & & & nasilan & 7 & 10,9 \\
\hline \multirow[t]{3}{*}{ sklon porocima } & 3 & 6,3 & & & & ohol & 6 & 9,4 \\
\hline & & & & & & razmetljiv & 4 & 6,3 \\
\hline & & & & & & svadljiv & 4 & 6,3 \\
\hline
\end{tabular}

Vrednosti ženskih likova zastupljene su sa 37,5\% u čitanci za SJ, $39 \%$ u čitanci za SKN i 20,3\% u čitanci za MJ. Najfrekventnije vrednosti ženskih likova (Tabela 6) su i dalje povezane sa promovisanjem izrazito patriharhalno ograničavajućih vrednosti u čitankama na srpskom jeziku. U čitanci za MJ vrednosti ženskih likova su drugačije i ne podupiru ovakvu težnju u potpunosti.

Tabela 6 - Vrednosti ženskih likova

\begin{tabular}{lllllllll}
\hline Čitanka za SJ & \multicolumn{3}{c}{$\begin{array}{l}\text { Čitanka za } \\
\text { SKN }\end{array}$} & & & Čitanka za MJ & \\
\hline Vrednost & F & \% & Vrednost & F & \% & Vrednost & f & \% \\
\hline tradicionalizam & 8 & 16,7 & brak & 5 & 12,2 & ljubav & 5 & 7,8 \\
\hline brak & 7 & 14,6 & tradicionalizam & 4 & 9,8 & & \\
\hline porodica & 7 & 14,6 & ljubav & 4 & 9,8 \\
\hline \multicolumn{6}{c}{ f=frekvencija, \%=postotak } \\
\end{tabular}

Karakterne vrednosti muških likova u tekstovima čitanke za SJ prisutne su sa procentom od 75\%, za SKN 63,4\% i za MJ 34,4\%, odnosno više nego dvostruko manje u odnosu na čitanku za SJ (Tabela 7). Autori tekstova u čitanci za SJ propagiraju ,patriotizam” i ,život u skladu sa učenjem vere" kao najveće vrednosti muških likova, a u čitanci za SKN „obrazovanost i znanje” i ,ljubav”. Autori čitanke za SKN napravili su 
korak napred u razbijanju očekivanih, nekritički prihvaćenih obrazaca vrednosti muških likova. Isto tako, u tekstovima čitanke za MJ najvišim vrednostima muških likova smatraju se „lična sloboda” i „rad i marljivost", što je suprotno vrednostima iz čitanke za SJ, jer se u njoj navedene osobine ni ne spominju.

Tabela 7 - Vrednosti muških likova

\begin{tabular}{|c|c|c|c|c|c|c|c|c|}
\hline Čitanka za SJ & & & $\begin{array}{l}\text { Čitanka za } \\
\text { SKN }\end{array}$ & & & Čitanka za MJ & & \\
\hline Vrednost & $\mathbf{F}$ & $\%$ & Vrednost & $\mathbf{F}$ & $\%$ & Vrednost & f & $\%$ \\
\hline patriotizam & 13 & 27,1 & $\begin{array}{l}\text { obrazovanost i } \\
\text { znanje }\end{array}$ & 7 & 17,1 & lična sloboda & 6 & 9,4 \\
\hline $\begin{array}{l}\text { život u sladu sa } \\
\text { učenjem vere }\end{array}$ & 9 & 18,8 & ljubav & 6 & 14,6 & rad i marljivost & 6 & 9,4 \\
\hline tradicionalizam & 9 & 18,8 & tradicionalizam & 4 & 9,8 & ljubav & 5 & 7,8 \\
\hline sloboda & 6 & 12,5 & patriotizam & 4 & 9,8 & $\begin{array}{l}\text { obrazovanost } \mathrm{i} \\
\text { znanje }\end{array}$ & 5 & 7,8 \\
\hline porodica & 6 & 12,5 & porodica & 4 & 9,8 & & & \\
\hline $\begin{array}{l}\text { iskazivanje nac. } \\
\text { prip. }\end{array}$ & 6 & 12,5 & tradicionalizam & 4 & 9,8 & & & \\
\hline rad i marljivost & 6 & 12,5 & & & & & & \\
\hline $\begin{array}{l}\text { visok mat. } \\
\text { standard }\end{array}$ & 4 & 8,3 & & & & & & \\
\hline ljubav & 4 & 8,3 & & & & & & \\
\hline kolektivizam & 4 & 8,3 & & & & & & \\
\hline
\end{tabular}

$\mathrm{f}=$ frekvencija, $\%=$ postotak

Postoji razlika između zastupljenosti interesovanja ženskih i muških likova. U čitanci za SJ u 11\% tekstova govori se o interesovanjima ženskih likova, za SKN 29,3\% i za MJ samo 10,9\%. Interesovanja muških likova prisutna su u 72,9\% tekstova u čitanci za SJ, 63,4 \% za SKN i tek $25 \%$ za MJ. „Porodični život (brak i deca)” je domen najviše opisivan u pogledu interesovanja ženskih likova u obe čitanke na srpskom jeziku, dok u čitanci za MJ nema dominantnih interesovanja. Interesovanja muških 
likova opisana su mnogo šire u sve tri čitanke (Tabela 8). Razlika je uočljiva i vrednosno neuporediva - dok autori tekstova u čitanci za SJ promovišu „vojsku i vojne stvari” kao najveća interesovanja muških likova, u čitanci za SKN je to „vlastito školovanje i obrazovanje” a u čitanci za MJ „rad i uspeh u struci”. Ovo ide u prilog činjenici o reprodukciji stereotipnih vrednosi za žene i muškarce.

Tabela 8 - Interesovanja muških likova

\begin{tabular}{|c|c|c|c|c|c|c|c|c|}
\hline Čitanka za SJ & & & $\begin{array}{l}\text { Čitanka za } \\
\text { SKN }\end{array}$ & & & Čitanka za MJ & & \\
\hline Interesovanje & $\mathbf{F}$ & $\%$ & Interesovanje & f & $\%$ & Interesovanje & f & $\%$ \\
\hline $\begin{array}{l}\text { vojska i vojne } \\
\text { stvari }\end{array}$ & 15 & 31,3 & $\begin{array}{l}\text { vlastito } \\
\text { školovanje i } \\
\text { obrazovanje }\end{array}$ & 8 & 19,5 & $\begin{array}{l}\text { rad i uspeh u } \\
\text { struci }\end{array}$ & 7 & 10,9 \\
\hline $\begin{array}{l}\text { briga za } \\
\text { životinje i } \\
\text { stoku }\end{array}$ & 7 & 14,6 & $\begin{array}{l}\text { rad i uspeh u } \\
\text { struci }\end{array}$ & 6 & 14,6 & umetnost & 5 & 7,8 \\
\hline $\begin{array}{l}\text { nac. prošlost } \\
\text { i sudbina } \\
\text { vlastite nacije }\end{array}$ & 7 & 14,6 & $\begin{array}{l}\text { prijateljstva i } \\
\text { poznanstva }\end{array}$ & 5 & 12,2 & $\begin{array}{l}\text { društvene } \\
\text { nauke }\end{array}$ & 4 & 6,3 \\
\hline $\begin{array}{l}\text { porodični život } \\
\text { (brak i deca) }\end{array}$ & 6 & 12,53 & umetnost & 5 & 12,2 & & & \\
\hline umetnost & 4 & 8,3 & $\begin{array}{l}\text { porodični život } \\
\text { (brak i deca) }\end{array}$ & 4 & 9,8 & & & \\
\hline $\begin{array}{l}\text { vera i verski } \\
\text { život }\end{array}$ & 4 & 8,3 & $\begin{array}{l}\text { briga za } \\
\text { životinje i stoku }\end{array}$ & 4 & 9,8 & & & \\
\hline
\end{tabular}

\section{Zaključak}

Rezultati rodno osetljive analize čitanki za osmi razred osnovne škole za SJ, SKN i MJ pokazuju da muškarci dominiraju i kao autori književnih tekstova i kao likovi reprezentovani u njima i na slikovnim prilozima uz tekst. Oni su glavni nosioci radnje i sukoba, te inicijatori njihovog razrešavanja. 
Profesionalne uloge muških likova podupiru predstave u kojoj je muškarac taj koji se brine za opšto dobro naroda, poštuje tradiciju i običaje i vodi društvo u budućnost u kojoj nema mesta za ravnopravnost žena i muškaraca. Izostaje interkulturni dijalog na svim nivoima i zainteresovanost za drugost.

U takvom miljeu pozicija i uloga ženâ podređeni su interesima vladajućih muškaraca i većinom su pasivni. Delovanje ženskih likova usmereno je na nemu podršku muškog društva u kojem je fizička i emotivna briga za dobrobit drugih u porodici i društvu visoko kotirana. One su bezlične osobe utopljene u kolektivnu euforiju retradicionalizacije.

Pozitivna je pre svega karakterizacija muških likova kao osećajnih i saosećajnih u čitankama za SJ i SKN. Uz to, čitanka za SKN u celini i $\mathrm{u}$ pojedinim segmentima sadrži internacionalizovane principe rodne ravnopravnosti. Autorke uočavaju učenice kao direktne korisnice i otvoreno im se obraćaju i upotrebljavaju ROJ u metodološkom delu tematske jedinice. Odabir izbornih tekstova je po tematici rodno neutalan i postoji tendencija uvođenja doprinosa žena znanju i nauci. Takođe se registruje uspeo pokušaj da se u okviru obaveznih tekstova odaberu oni odlomci u kojima se pojavljuju ženski likovi, mada većinom kao pasivna podrška.

Prema trenutnim saznanjima, do sada kod nas nije izvršena rodno osetljiva analiza udžbenika za nastavu koja se odvija na mađarskom jeziku. Dobijeni podaci pokazuju niz konceptualnih razlika čitanke za MJ u odnosu na druge dve, što se ne može objasniti isključivo činjenicom da je napisana na drugom nastavnom jeziku. Izbor tekstova, tematika, kao i grafička i likovna opremljenost tekstova, usmereni su u celini ka apstraktnoj umetnosti i profinjenom razvoju kulturno-nacionalnog identiteta. Samim tim je kvatnitativno više elemenata rodno neutralnih. Međutim, kada parametar rodnosti postoji, onda odiše tradicionalno patrijarhalnim vrednostima.

Čitanke i dalje reflektuju rodne sterotipe. Ne postoji zainteresovanost za prava žena i probleme nejednakosti. Programi za SJ, SKN i MJ propagiraju istovremeno zvaničnu obrazovnu politiku višejezične nastave u Vojvodini i Republici Srbiji i sinhroni i dijahroni društveni konstrukt rodne (ne)jednakosti. Pitanje je do koje mere je dopuštena autonomija autorskog i recenzentskog tima u izboru i uobličavanju tekstova? Na koji način on segmentira književna dela u tematsku celinu? Kako integriše ciljeve i standarde postignuća učenika i učenica i standarde kvaliteta udžbenika? Ova analiza potvrđuje neusaglašenosti i danas ne postoje mehanizmi koji bi ih kontrolisali i otklonili. 


\title{
GENDER SENSITIVE ANALYSIS OF THE TEXTBOOK FOR THE EIGHTH GRADE OF ELEMENTARY SCHOOL FOR SERBIAN, SERBIAN AS A SECOND LANGUAGE, AND HUNGARIAN LANGUAGE
}

\begin{abstract}
SUMMARY
Abstract: Numerous studies confirm that the traditional patriarchal model is present in the elementary school curricula. They also confirm the existence of hidden or invisible curriculum, which transfers improper and unplaned value attitudes and behavior patterns to the pupils. Thus, boys and girls are socialized for different roles, indirectly affecting the formation of gender-based behavior models. The aim of this paper is to deconstruct the content and structure of textbooks for the eighth grade of elementary school for Serbian language, Serbian as a second language, and Hungarian, which are currently in use in Vojvodina, through the prism of gender-sensitive analysis, in order to determine whether the process of integrating gender equality has been revived in the textbooks, in terms of non-discriminatory educational practices. For gender-sensitive analysis of the textbooks, I used the research instruments created for the purpose of the regional project „Gender Sensitive Textbooks and Classroom Practice in the Balkan Region" (from 09/2005 to 09/2007). The results confirm that the textbooks continue to reflect gender stereotypes both in their content and concept; there is no interest for women's rights and problems of inequality. Men dominate both as authors of literary works and as the characters represented in the works, as well as the characters on the images along with the text. They are the main holders of action, and conflict, and initiators of its resolution. Actions of female characters are aimed support of the male society in which the physical and emotional care for the welfare of others in the family and society is highly ranked. Today there are no mechanisms to control and eliminate the existing incompliance to the standard of quality of the textbooks that relate to the principles of equal opportunities and non-discriminatory practices with the content and concept of the textbook.
\end{abstract}

Key words: textbooks for the eight grade of elementary school, Hungarian language, gender-sensitive analysis, Serbian language. 


\section{Literatura}

Baranović, B., Jugović, I., Doolan, K. (2008). Kojeg su roda čitanke iz književnosti?. Zagreb: Institut za društvena istraživanja.

Dijk, T. van (1993). Principles Of Critical Discourse Analysis. Discourse \& Society, 4 (2), 249-283.

Dijk, T. A. van (2009). Critical Discourse Studies: A Sociocognitive Approach. In: Wodak, Ruth, Meyer, Michael (Eds.), Methods Of Critical Discourse Analasys. Second Edition 62-86). Los Angeles, London, New Dwlhi, Singapore, Washington DC: Sage.

Đorić, G., Žunić, N., Obradović-Tošić, N. (2010). Obrazovanje za rodnu ravnopravnost. Analiza nastavnog materijala za Građansko vaspitanje. Beograd: UNDP.

Grbić, M. (2007). Analiza diskursa rodnih stereotipa u udžbenicima za osnovnu školu (magistarski rad). Novi Sad: Centar za rodne studije, ACIMSI.

Jarić, I. (2002). Škola. U: Blagojević M. (Ur.), Mapiranje mizoginije u Srbiji: diskursi i prakse (495-503). Beograd: Kvinn Till Kvinn.

Kovačević, A., Kosić, S., Jurlina, T. (2004). Rodni stereotipi u udžbenicima za osnovnu školu (I, IV i VIII razred) u Crnoj Gori. Kotor: Foundation Open Society predstavništvo CG, ANIMA.

Kožul, M. (2007). Udžbenik-nastavnik: Rodni stereotipi u udžbenicima srpskog kao nematernjeg jezika i uloga nastavnika u njihovom održavanju/prevazilaženju (magistarski rad). Novi Sad: Centar za rodne studije, ACIMSI.

Marić, S. (2011). Rodno osetljiva analiza teksta udžbenika muzičke kulture: osnovne i srednje škole u Srbiji (2011-2012) (master rad). Novi Sad: Centar za rodne studije, ACIMSI.

Milinković, M. (2008). Rodna senzitivnost kao kriterijum kvaliteta osnovnoškolskih udžbenika (diplomski rad). Odsek za pedagogiju Filozofskog fakulteta.

Nikolić, G. (2008). Rodni stereotipi u udžbenicima za mlađe razrede osnovnih škola za decu sa lakom nedovoljnom razvijenošću (magistarski rad). Novi Sad: Centar za rodne studije, ACIMSI.

Paseka, A. (2004). Udžbenici kao instrumenti „tajnog nastavnog plana“ škole“. U: GENDER perspektiva u nastavi: mogućnosti $i$ poticaji (52-59). Sarajevo: Fondacija Heinrich Böll, regionalni ured Sarajevo, Kulturkontakt Austrija.

Petrić, B. (2006). Rečnik reforme obrazovanja. Novi Sad: Platoneum, Misao, Pedagoški zavod Vojvodine. 
Plut, D. (2004). Socijalizacijski obrasci udžbenika i rodni stereotipi. U: Prevazilaženje rodnih stereotipa u osnovnom obrazovanju (35-52). Budva: Foundation Open Society Institute, Predstavništvo CG.

Pravilnik o standardima kvaliteta udžbenika i uputstvo o njihovoj upotrebi (2010), Službeni glasnik RS - Prosvetni glasnik, br. 1/10.

Puhalo, S., Milinović, J. (2007). Kog su roda čitanke? Banja Luka: Vlada Republike Srpske, Gender centar-Centar za jednakost ravnopravnost polova.

Savić, S. (1993). Diskurs analiza. Novi Sad: Filozofski fakultet.

Savić, S. (2009). Kritička anliza udžbenika veronauke u Srbiji (neobjavljen rukopis).

Savić, S., Ćanak, M., Mitro, V., Štasni, G. (2009). Rod i jezik. Novi Sad: Ženske studije i istraživanja i Futura publikacije.

Stefanović, J., Glamočak, S. (2008). Rod u čitankama i nastavi srpskog jezika u osnovnoj školi. Valjevo: Grupa za emancipaciju žena „Hora“.

Stjepanović-Zaharijevski, D., Gavrilović, D., Petrušić, N. (2010). Obrazovanje za rodnu ravnopravnost. Analiza nastavnog materijala za osnovnu i srednju školu. Niš: UNPD

Toldi, E. (2005). Iskustva u izradi udžbeničkog kompleta na mađarskom jeziku. U: Toldi, E. (Ur.), Metodologija pisanja udžbenika (27-34). Novi Sad: Pedagoški zavod Vojvodine.

Zakon o udžbenicima $i$ drugim nastavnim sredstvima (2015), Slušbeni glasnik RS, br. 68/2015. 